\section{Influence Of Genetic Polymorphisms In Genes of Bone Remodeling And Angiogenes is Process In The Apical Periodontitis}

Jardel Francisco Mazzi-Chaves', Igor Bassi Ferreira Petean1, Isadora Mello Vilarinho Soares1, Alessandro Guimarães Salles 2,3, Lívia Azeredo Alves Antunes ${ }^{2,3}$, Raquel Assed Bezerra Segato ${ }^{4}$, Léa Assed Bezerra da Silva ${ }^{4}$, Erika Calvano Küchler ${ }^{4}$, Leonardo Santos Antunes ${ }^{2,3}$, Manoel Damião Sousa-Neto ${ }^{1}$

Persistent apical periodontitis (AP) is a situation involving an inflammatory and immune response caused mainly by anaerobic polymicrobial infection of the root canal system and the outcome and follow-up of the root canal treatment has been reported as intimately related to host response. The apical periodontitis repair might be associated with genetic polymorphisms. This study aimed to evaluate the association between HIF1A genetic polymorphisms (rs2301113 and rs2057482) with PAP in Brazilian patients. Subjects with at least 1 year of follow-up after root canal therapy (RCT) were recalled. Sixty-four subjects with signs/symptoms of PAP and 84 subjects with root canal-treated teeth exhibiting healthy perirradicular tissues (healed) were included. Genomic DNA was extracted from saliva and used for HIF1A genotyping by real-time PCR. Genotype and allele frequencies were compared by $\chi^{2}$ or Fisher's exact tests and odds ratio was implemented, using Epi Info 3.5.2. All tests were performed with an established alpha of 0.05. There was no association between allele and genotype distribution for HIF1As polymorphisms and PAP ( $p>0.05$ ). The genetic polymorphisms in HIF1A were not associated with persistent apical periodontitis.

\author{
'Department of Restorative Dentistry, \\ School of Dentistry of Ribeirão \\ Preto, USP- Universidade de São \\ Paulo, Ribeirão Preto, SP, Brazil \\ ${ }^{2}$ Clinical Research Unit, \\ UFF - Universidade Federal \\ Fluminense, Niterói, RJ, Brazil \\ ${ }^{3}$ Department of Specific Formation, \\ School of Dentistry of Nova \\ Friburgo, UFF - Universidade Federal \\ Fluminense, Nova Friburgo, RJ, Brazil \\ ${ }^{4}$ Department of Pediatric Dentistry, \\ School of Dentistry of Ribeirão \\ Preto, USP - Universidade de São \\ Paulo, Ribeirão Preto, SP, Brazil
}

Correspondence: Prof. Dr. Leonardo Santos Antunes, Rua Mario Santos Braga, 28, Centro, CEP: 24020140, Niterói, Rio de Janeiro, e-mail: leonardoantunes@id.uff.br

Key words: HIF1A, genetic polymorphisms, apical periodontitis, angiogenesis

\section{Introduction}

Apical periodontitis (AP) is an inflammatory and immune response condition, which the main cause, is the anaerobic polymicrobial infection of the dental pulp and root canals (1-6). This inflammation damages tissues and results in bone destruction around the root apex $(1-3,6)$.

Several evidences demonstrate that inflammatory lesions are characterized by cystic formation, nutrient depletion and ischaemia hypoxia in the central areas of the inflamed AP. The episodes of tissue hypoxia occur as a result of increased metabolism and reduced oxygen supply $(2,4,7)$. The hypoxia and inflammatory environments may induce angiogenic processes $(2,8)$, cell proliferation or cell protection through several mechanisms such as autophagy to aid cells overcome this situation (2). In fact, one of the most important factor that affects acute and chronic inflammation is the oxygen (2). Hypoxia is a key feature of inflammatory tissues due to elevated oxygen consumption by infiltrated inflammatory cells, which must adapt to hypoxic environments and maintain the function of the innate immune system against infectious microorganisms $(2,6)$.

Inside the root canals and surround periapical tissues, hypoxia plays pathogenic roles in the development of $A P$, which involve hypoxia-inducible factor 1 (HIF-1) $(2,6)$.The HIF-1 is a local regulator especially related to angiogenesis but is also receiving prominence by modulating osteoclastogenesis and osteoclastic activity $(9,10)$. HIF1A gene encodes the alpha subunit of transcription factor HIF$1 \alpha$, which regulates oxygen dependent gene transcription $(4,7)$. In the hypoxia signaling pathway HIF-1 $\alpha$ plays a major role. This factor is 02 -sensitive, and in the presence of 02 , HIF- $1 \alpha$ is hydrolysed and degraded. During hypoxia, HIF1A is stabilized and translocated to the nucleus where it induces transcription of hypoxia-regulated genes, particularly associated with increased angiogenesis (10). However, it has been reported that HIF-1 $\alpha$ is also involved in the regulation of the osteoclastogenesis and osteoclast activation $(2,6,9,10)$.

HIF1A is expressed in innate and adaptive immune cells, including macrophages (11), neutrophils (12), dendritic cells (13), and lymphocytes (14). Recent studies have been demonstrating that HIF-1 $\alpha$ plays an important role in the process of AP wound healing $(2,6)$, playing a protective role downregulating of NF- $\mathrm{KB}$, proinflammatory cytokines, M1 macrophages and osteoclastogenesis (2). Although recent studies have suggested that HIF- $1 \alpha$ are a protective factor for AP, the connection between the gene HIF1A and AP have 
not been evaluated yet. Thus, based on these evidences, this study proposed to evaluate the association between persistent AP and the genetic polymorphisms rs2301113 and rs2057482 in HIF1A.

\section{Material and Methods}

\section{Sample Selection and Patients}

After the approval of the Ethics Committees (CAAE: 74708517.7.0000.5419 and 37717414.0.0000.5243), all subjects were informed about the research and a consent term was signed for each one.

Initially, subjects who received endodontic treatment at the School of Dentistry of Ribeirão Preto, University of São Paulo, SP, Brazil and at the Fluminense Federal University, RJ, Brazil were screened. Patients that presented pulp necrosis and apical periodontitis at the time of endodontic treatment (15-18) and at least 1 year follow-up were included.

As an inclusion criterion, only subjects with at least one root canal-treated tooth, no specific reason for root canal treatment failure and good or regular health condition, were included. Patients with unsatisfactory endodontic treatment (obturation more than $2 \mathrm{~mm}$ shorter from the radiographic $\vec{s}$ apex or overfilled from the root apex and/or with voids, inadequate density, unfilled canals, or poor condensation), medical conditions, immunologically compromised; vertical root fracture; presence of microleakage and absence of final restoration were excluded.

\section{Phenotype Determination}

During follow-up visits, the phenotype was determined based on radiographic and clinical aspects. Immediate postoperative radiographs were compared to radiographs obtained during the follow-up session. All radiographs were taken through the bisector technique to allow the comparison between sessions and evaluated by an experienced and calibrated endodontist. If the examiner was not able to clearly determine the phenotype, a second observer was consulted until an agreement was reached between the examiners. In patients who had endodontic treatment in multirooted teeth, the phenotype was

Table 1. Genes and markers studied in the present study

\begin{tabular}{lccccc}
\hline Gene & Chromosome & $\begin{array}{c}\text { Genetic } \\
\text { Polymorphism }\end{array}$ & $\begin{array}{c}\text { Functional } \\
\text { Consequence }\end{array}$ & Base Change & Global MAF \\
\hline HIF1A & Chr. 14 & rs2301113 & intron variant & A/C & 0.47 \\
HIF1A & Chr. 14 & rs2057482 & intron variant & C/T & 0.24 \\
\hline
\end{tabular}

Bold form indicates ancestral allele; MAF means minor allele frequency. Data obtained from databases: http://www.ncbi.nlm.nih.gov/snp/;http://genome.ucsc.edu/;http://www.thermofisher. com/. *Multivariation model using time of follow-up as a covariant. Bold forms indicated statistical significance; OR means Odds Ratio; CI means Confidence Interval. determined from the worst result found in the roots.

The data from this study were classified according to criteria used in a previous study (16) as follow: 1) persistent apical periodontitis (PAP) group, which was defined as a lack of healing with apparently well obturated root canal system(s) as determined by a radiographic examination, the preexisting radiographic lesion remained the same size or increased in size, and the presence of a clinical sign or symptom of periapical disease (ie, sinus tract, pain, and swelling), constituting. 2) Healed group was assigned by subjects who had endodontic treatment accomplished with no swelling and pain absence, sinus tract disappearance, no function loss, and no tissue destruction.

\section{DNA Extraction and Genotyping}

During the follow-up visit, after the radiographic examination, saliva samples were collected from all included patients. The genotyping analysis was performed from genomic DNA extracted from buccal cells isolated from saliva as previously described (19). A spectrophotometer (NanoDrop 1000, Thermo Scientific, Wilmington, DE, USA) determined the quantity and purity of the DNA. Two genetic polymorphisms in HIF1A genes were selected and are described in the Table 1.

Real-time polymerase chain reaction (PCR) using the TaqMan assay (20) was used to perform genotyping. Water was used as a non-model control (negative control) to ensure the quality control of genotyping reactions.

\section{Statistical Analysis}

The Epi Info 3.5.2 software was used to analyze the data obtained. Test-t was performed to calculate the age differences between groups. Fisher's exact and chi-square tests were used to analyze the demographic difference (age, sex, ethnicity, healthy condition and habits) between groups.

Chi-square or Fisher's exact tests and odds ratio were used to compare allele and genotype distributions between PAP and healed groups. A logistic regression analysis was also implemented using time of follow-up as co-variate. All tests were performed with an established alpha of 0.05 . Hardy-Weinberg equilibrium was evaluated using the chi-square test.

\section{Results}

The studied group was composed by 150 patients, in which 109 (72.67\%) were females and 41 (27.33\%) were males. Eight-two (54.67\%) patients were Caucasians and 68 (45.33\%) 
African-descendants with age ranging from 16 to 83 (Table 2).

Therefore, a total of $42.7 \%(n=64)$ of the evaluated patients showed PAP and $57.3 \%(n=86)$ were classified as healed, and the follow-up time ranged between 12 and 84 months after the endodontic treatment.

Table 2. Demographic characteristics distribution of studied patients between groups: Persistent Apical Periodontitis (PAP) x healed

\begin{tabular}{lccc}
\hline Characteristic & PAP (n=64) & Healed (n=86) & p-value* \\
\hline Age [Mean (SD)] & $45.6(13.2)$ & $47.7(13.7)$ & $0.42^{*}$ \\
Sex & & & \\
Female (\%) & $44(40.4)$ & $65(59.6)$ & $0.35^{* * *}$ \\
Male (\%) & $20(48.8)$ & $21(51.2)$ & \\
Ethnicity & & & \\
Caucasians (\%) & $34(53.1)$ & $48(55.8)$ & $0,91^{* * *}$ \\
African-descendants (\%) & $30(44.1)$ & $38(55.9)$ & \\
Healthy condition & & & \\
Any (\%) & $26(47.3)$ & $29(52.7)$ & $0.38^{* * *}$ \\
None (\%) & $38(40.0)$ & $57(60.0)$ & \\
Habits & $13(56.5)$ & $10(43.5)$ & $0,10^{* * *}$ \\
Smoker (\%) & $49(38.6)$ & $78(61.4)$ & \\
Nonsmoker (\%) & & & \\
\hline
\end{tabular}

* t-test; **Chi-square test, bold forms indicated statistical significance.
Table 3 demonstrated genotype and allele distributions between PAP and healed groups. The genetic polymorphisms in HIF1A were not associated with PAP ( $p>0.05)$.

Table 4 shows the results of the multivariate analysis adjusting by the follow-up time, which was not associated with the persistent PAP ( $p>0.05)$.

\section{Discussion}

In the past decades, the understanding of the genetic contributions to the risk of developing AP and the risk to present PAP was explored in some studies $(1,18,21-26)$. In a recent review, Aminoshariae and Kulild (27) showed that polymorphisms could be biological modifiers of some individual susceptibility. In fact, many of these previous studies proposed that some genetic polymorphisms could be a genetic marker for PAP $(1,28,18,21-25,27,29-31)$.

Huang et al. (6) demonstrated that hypoxia is presented in inflammatory AP by immunoblotting and potentially interacts with the immune and inflammatory responses. In our present study, we did not find an association between genetic polymorphisms in HIF1A and PAP, although HIF1A was a promising candidate gene. Hirai et al. (2) demonstrated that the activation of HIF$1 \alpha$ exhibited an anti-inflammatory effect in

Table 3. HIF1A Genotypes and Alleles distribution in patient between Persistent Apical Periodontitis (PAP) and healed groups

\begin{tabular}{|c|c|c|c|c|c|c|c|c|c|}
\hline $\begin{array}{l}\text { Gene } \\
\text { (Polymorphism) }\end{array}$ & Groups & \multicolumn{3}{|c|}{ Genotype n (\%) } & \multicolumn{4}{|c|}{ Allele n (\%) } & \\
\hline \multirow{3}{*}{$\begin{array}{l}\text { HIF1A } \\
\text { (rs2301113) }\end{array}$} & & $\mathrm{AA}$ & AC & $\mathrm{CC}$ & p-value* & A & $\mathrm{C}$ & p-value* & OR $(95 \% \mathrm{CI})$ \\
\hline & PAP & $24(37.5)$ & $28(43.8)$ & $12(18.8)$ & \multirow{2}{*}{0.44} & $76(59.4)$ & $52(40.6)$ & \multirow{2}{*}{0.36} & \multirow{2}{*}{$0.80(0.51-1.28)$} \\
\hline & Healed & 24 (27.9) & $45(52.3)$ & $17(19.8)$ & & $93(54.1)$ & 79 (45.9) & & \\
\hline \multirow{3}{*}{$\begin{array}{l}\text { HIF1A } \\
\text { (rs2057482) }\end{array}$} & & $\mathrm{CC}$ & CT & TT & $p$-value ${ }^{*}$ & C & $\mathrm{T}$ & $\mathrm{p}$-value $\mathrm{e}^{*}$ & OR $(95 \% \mathrm{CI})$ \\
\hline & PAP & $32(68.1)$ & 11 (23.4) & $4(8.5)$ & \multirow{2}{*}{0.48} & 75 (79.8) & $19(20.2)$ & \multirow{2}{*}{0.41} & \multirow{2}{*}{$0.76(0.40-1.45)$} \\
\hline & Healed & $36(58.1)$ & 21 (33.9) & $5(8.1)$ & & $93(75.0)$ & $31(25.0)$ & & \\
\hline
\end{tabular}

*Chi-square test, bold forms indicated statistical significance; OR means Odds Ratio; CI means Confidence Interval.

Table 4. HIF1A multivariation model

\begin{tabular}{lcccc}
\hline Gene (Polymorphism) & Reference & Genotype & p-value* & OR (95\%CI) \\
\hline HIF1A (rs2301113) & AA & AC & 0.09 & $0.51(0.23-1.11)$ \\
& & CC & 0.39 & $0.66(0.25-1.71)$ \\
HIF1A (rs2057482) & CC & CT & 0.23 & $0.58(0.24-1.40)$ \\
& & TT & 0.94 & $0.95(0.23-3.89)$ \\
\hline
\end{tabular}

*Multivariation model using time of follow-up as a covariant. Bold forms indicated statistical significance; OR means Odds Ratio; CI means Confidence Interval. 
AP, and they proposed that HIF-1 $\alpha$ might be related to infiltration of myeloid cells in AP inflammation. Their gene expression analysis also indicated a possible mechanism of the less inflammatory state mediated by activation of HIF- $1 \alpha$ through downregulation of NF-KB activation and subsequent proinflammatory gene expressions.

The genetic polymorphism rs2301113 in HIF1A was associated with the lung cancer outcome but not for colorectal cancer $(3,32)$. On the other hand, the genetic polymorphism rs2057482 was associated with the efficiency of the chemotherapy in colorectal cancer patients (32) and with the prognosis of perimenopause coronary artery disease (33). In our study, we were not able to identify a polymorphism in HIF1A as a marker to the endodontic treatment outcome prognosis. This could be related with the fact that these polymorphisms are not associated with PAP or with the fact that this gene has a small effect in the prognosis of the endodontic treatment, and this effect could only be detect in a larger sample size. It is also possible that other genetic polymorphisms in this same gene are involved in PAP, since HIF- $1 \alpha$ plays an important role in angiogenesis and osteogenesis.

In fact, activation of the HIF-1 $\alpha$ pathway accelerates bone regeneration, reduces inflammatory cell infiltration and promotes wound healing (34-36). An association between HIF- $1 \alpha$, RANKL and angiogenesis has also been showed by some studies $(37,38)$. In addition, studies demonstrated that HIF- $1 \alpha$ promotes increased vascular endothelial growth factor, which in turn recruit osteoclast to the remodeling area, to stimulate osteoclast differentiation and to promote osteoclast resorption (9,39-42).

Briefly, hypoxia-based strategies in dentistry are emerging in all dental specialties (4). Further research on this topic is necessary to harvest the benefits of these approaches in the future and identify the most applicable screening strategy in the endodontic research. According to the results of the present study, it can be concluded that the genetic polymorphisms rs2301113 and rs2057482 in HIF1A were not associated with persistent apical periodontitis.

\section{Resumo}

A periodontite apical persistente (PAP) é uma condição que envolve uma resposta inflamatória e imunológica causada principalmente por infecções polimicrobianas de origem anaeróbia no sistema de canais radiculares, tornando o resultado e o acompanhamento do tratamento do canal radicular intimamente relacionados à resposta do hospedeiro. 0 reparo da periodontite apical pode estar associado a polimorfismos genéticos. Este estudo teve como objetivo avaliar a associação entre os polimorfismos genéticos do HIF1A (rs2301113 e rs2057482) com a PAP em pacientes brasileiros. Indivíduos com pelo menos 1 ano de acompanhamento após o tratamento do canal radicular (TCR) foram agendados para consulta de acompanhamento. Sessenta e quatro indivíduos com sinais/sintomas de PAP e 84 indivíduos com dentes tratados endodonticamente e tecidos perirradiculares saudáveis (cicatrizados) foram incluidos no presente estudo. 0 DNA genômico foi extraído da saliva e utilizado para a genotipagem do HIF1A por PCR em tempo real. 0 genótipo e as frequências alélicas foram comparados por teste $\chi^{2}$ ou exato de Fisher e odds-ratio foi implementado por meio do software Epi Info 3.5.2. Todos os testes realizados foram estabelecidos $\operatorname{com} \alpha=0,05$. Não houve associação entre alelo e distribuição genotípica para polimorfismos do HIF1A e PAP $(p>0,05)$. Os polimorfismos genéticos em HIF1A não foram associados à periodontite apical persistente.

\section{Acknowledgements}

This project was supported by the Brazilian funding agency - National Counsel of Technological and Scientific Development (CNPq) 303663/2014-6 (LAS and ECK).

\section{References}

1. Siqueira JF, Rôças IN. Diversity of endodontic microbiota revisited. J Dent Res 2009; 88:969-981.

2. Hirai $K$, Furusho H, Hirota $K_{1}$ Sasaki H. Activation of hypoxia-inducible factor 1 attenuates periapical inflammation and bone loss. Int J Oral Sci 2018;10:12.

3. Liu B, Liu Q, Song Y, Li X, Wang Y, Wan S, et al. Polymorphisms of HIF1A gene are associated with prognosis of early stage non-small-cell lung cancer patients after surgery. Med Oncol 2014;31:877.

4. Müller AS, Janjic K, Lilaj B, Edelmayer M, Agis H. Hypoxia-based strategies for regenerative dentistry-Views from the different dental fields. Arch Oral Biol 2017;81:121-130.

5. He M, Bian Z. Expression of hypoxia-induced semaphorin 7A correlates with the severity of inflammation and osteoclastogenesis in experimentally induced periapical lesions. Arch Oral Biol 2017;75:114119.

6. Huang HY, Wang WC, Lin PY, Huang CP, Chen CY, Chen YK. The roles of autophagy and hypoxia in human inflammatory periapical lesions. Int Endod J 2018;51:e125-145.

7. Janjic K, Lilaj B, Moritz A, Agis H. Formation of spheroids by dental pulp cells in the presence of hypoxia and hypoxia mimetic agents. Int Endod J 2018;51:e146-156.

8. Konisti S, Kiriakidis S, Paleolog EM. Hypoxia-a key regulator of angiogenesis and inflammation in rheumatoid arthritis. Nat Rev Rheumatol 2012;8:153-162.

9. Gomes-Filho JE, Wayama MT, Dornelles RCM, Ervolino E, Yamanari GH, Lodi CS, et al. Raloxifene modulates regulators of osteoclastogenesis and angiogenesis in an oestrogen deficiency periapical lesion model. Int Endod J 2015;48:1059-1068.

10. Palazon A, Goldrath AW, Nizet V, Johnson RS. HIF Transcription Factors, Inflammation, and Immunity. Immunity 2014;41:518-528.

11. Cramer T, Yamanishi Y, Clausen BE, Förster I, Pawlinski R, Mackman N, et al. HIF-1alpha is essential for myeloid cell-mediated inflammation. Cell 2003;112:645-657.

12. Walmsley SR, Print C, Farahi N, Peyssonnaux C, Johnson RS, Cramer T, et al. Hypoxia-induced neutrophil survival is mediated by HIF-1alphadependent NF-kappaB activity. J Exp Med 2005;201:105-115.

13. Jantsch J, Chakravortty D, Turza N, Prechtel AT, Buchholz B, Gerlach $R G$, et al. Hypoxia and hypoxia-inducible factor-1 alpha modulate lipopolysaccharide-induced dendritic cell activation and function. J Immunol 2008;180:4697-4705.

14. McNamee EN, Korns Johnson D, Homann D, Clambey ET. Hypoxia and hypoxia-inducible factors as regulators of T cell development, differentiation, and function. Immunol Res 2013;55(1-3):58-70.

15. Siqueira JF, Rôças IN, Provenzano JC, Daibert FK, Silva MG, Lima KC. Relationship between Fcgamma receptor and interleukin-1 gene polymorphisms and post-treatment apical periodontitis. J Endod 2009;35:1186-1192.

16. Morsani JM, Aminoshariae A, Han YW, Montagnese TA, Mickel A. Genetic Predisposition to Persistent Apical Periodontitis. J Endod 2011;37:455-459.

17. Siqueira JF, Rôças IN, Provenzano JC, Guilherme BPS. Polymorphism of the FcyRIlla gene and post-treatment apical periodontitis. J Endod 2011;37:1345-1348. 
18. Rôças IN, Siqueira JF, Del Aguila CA, Provenzano JC, Guilherme BPS, Gonçalves LS. Polymorphism of the CD14 and TLR4 genes and posttreatment apical periodontitis. J Endod 2014;40:168-172.

19. Küchler EC, Tannure PN, Falagan-Lotsch P, Lopes TS, Granjeiro JM, Amorim LMF. Buccal cells DNA extraction to obtain high quality human genomic DNA suitable for polymorphism genotyping by PCR-RFLP and Real-Time PCR. J Appl Oral Sci;20:467-471.

20. Ranade $\mathrm{K}$, Chang MS, Ting CT, Pei D, Hsiao CF, Olivier M, et al. Highthroughput genotyping with single nucleotide polymorphisms. Genome Res 2001;11:1262-1268.

21. Morsani JM, Aminoshariae A, Han YW, Montagnese TA, Mickel A. Genetic Predisposition to Persistent Apical Periodontitis. J Endod 2011;37:455-459.

22. Siqueira JF, Rôças IN, Provenzano JC, Guilherme BPS. Polymorphism of the FcyRllla gene and post-treatment apical periodontitis. J Endod 2011;37:1345-1348.

23. Menezes-Silva R, Khaliq S, Deeley K, Letra A, Vieira AR. Genetic susceptibility to periapical disease: conditional contribution of MMP2 and MMP3 genes to the development of periapical lesions and healing response. J Endod 2012;38:604-607.

24. Amaya MP, Criado L, Blanco B, Gómez M, Torres O, Flórez L, et al. Polymorphisms of pro-inflammatory cytokine genes and the risk for acute suppurative or chronic nonsuppurative apical periodontitis in a Colombian population. Int Endod J;46:71-78.

25. Dill A, Letra A, Chaves de Souza L, Yadlapati M, Biguetti CC, Garlet $\mathrm{GP}$, et al. Analysis of multiple cytokine polymorphisms in individuals with untreated deep carious lesions reveals IL1B (rs1143643) as a susceptibility factor for periapical lesion development. J Endod 2015;41:197-200.

26. Maheshwari K, Silva RM, Guajardo-Morales L, Garlet GP, Vieira AR, Letra A. Heat Shock 70 Protein Genes and Genetic Susceptibility to Apical Periodontitis. J Endod 2016;42:1467-1471.

27. Aminoshariae A, Kulild JC. Association of Functional Gene Polymorphism with Apical Periodontitis. J Endod 2015;41:999-1007.

28. Huang $\mathrm{HY}$, Wang $\mathrm{WC}$, Lin PY, Huang $\mathrm{CP}$, Chen $\mathrm{CY}$, Chen YK. The roles of autophagy and hypoxia in human inflammatory periapical lesions. Int Endod J 2018;51:e125-145.

29. Gomes MS, Blattner TC, Sant'Ana Filho M, Grecca FS, Hugo FN,

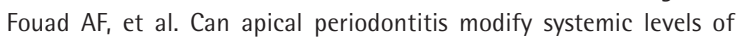
inflammatory markers? A systematic review and meta-analysis. J Endod 2013;39:1205-1217.

30. Paradowska-Gorycka A, Stypinska B, Pawlik A, Haladyj E, RomanowskaPróchnicka K, Olesinska M. HIF-1A gene polymorphisms and its protein level in patients with rheumatoid arthritis: a case-control study. Inflamm Res 2018;67:423-433.
31. Salles AG, Antunes LAA, Küchler EC, Antunes LS. Association between Apical Periodontitis and Interleukin Gene Polymorphisms: A Systematic Review and Meta-analysis. J Endod 2018;44:355-362.

32. Zhang $Y$, Wang $P$, Zhou X-C, Bao G-Q, Lyu Z-M, Liu X-N, et al. Genetic variations in the HIF1A gene modulate response to adjuvant chemotherapy after surgery in patients with colorectal cancer. Asian Pac J Cancer Prev 2014;15:4637-4642.

33. Guo N, Zhang N, Yan L, Cao X, Wang J, Wang Y. Correlation between genetic polymorphisms within the MAPK1/HIF-1/HO-1 signaling pathway and risk or prognosis of perimenopausal coronary artery disease. Clin Cardiol 2017;40:597-604.

34. Wan C, Gilbert SR, Wang $Y$, Cao $X$, Shen $X$, Ramaswamy G, et al. Activation of the hypoxia-inducible factor-1alpha pathway accelerates bone regeneration. Proc Natl Acad Sci U S A 2008;105:686-691.

35. Cummins EP, Seeballuck F, Keely SJ, Mangan NE, Callanan JJ, Fallon PG, et al. The hydroxylase inhibitor dimethyloxalylglycine is protective in a murine model of colitis. Gastroenterology 2008;134:156-165.

36. Botusan IR, Sunkari VG, Savu O, Catrina Al, Grünler J, Lindberg S, et al. Stabilization of HIF-1alpha is critical to improve wound healing in diabetic mice. Proc Natl Acad Sci U S A 2008;105:19426-19431.

37. Trebec-Reynolds DP, Voronov I, Heersche JNM, Manolson MF. VEGF-A expression in osteoclasts is regulated by NF-kappaB induction of HIF1alpha. J Cell Biochem 2010;110:343-351.

38. Dandajena TC, Ihnat MA, Disch B, Thorpe J, Currier GF. Hypoxia triggers a HIF-mediated differentiation of peripheral blood mononuclear cells into osteoclasts. Orthod Craniofac Res 2012;15:1-9.

39. Niida S, Kaku M, Amano H, Yoshida H, Kataoka H, Nishikawa $S$, et al. Vascular endothelial growth factor can substitute for macrophage colony-stimulating factor in the support of osteoclastic bone resorption. J Exp Med 1999;190:293-298.

40. Maes C, Carmeliet P, Moermans K, Stockmans I, Smets N, Collen D, et al. Impaired angiogenesis and endochondral bone formation in mice lacking the vascular endothelial growth factor isoforms VEGF164 and VEGF188. Mech Dev 2002;111:61-73.

41. Sipola A, Nelo K, Hautala T, Ilvesaro J, Tuukkanen J. Endostatin inhibits VEGF-A induced osteoclastic bone resorption in vitro. BMC Musculoskelet Disord 2006;7:56.

42. Knowles HJ, Athanasou NA. Hypoxia-inducible factor is expressed in giant cell tumour of bone and mediates paracrine effects of hypoxia on monocyte-osteoclast differentiation via induction of VEGF. J Pathol 2008;215:56-66. 